COVID-19 SALGINI SÜRECINDE KOBI'LERİN FİNANSAL GÖRÜNÜMÜNÜN DEĞERLENDİRILMESİ: DENIZLİ TEKSTILL İSLETMELERİ ÖRNEĞ $\dot{I}^{1}$

AN EVALUATION OF THE FINANCIAL OUTLOOK OF SMES DURING THE COVID-19 OUTBREAK: THE CASE OF DENIZLI TEXTILE BUSINESSES

\title{
Ilknur ESKINN
}

Geliş Tarihi: 22.09.2020

(Received)

ÖZ: Küçük ve orta ölçekli işletmeler (KOBİ'ler), girișimcilik faaliyetleriyle ülkelerin sosyo-ekonomik kalkınmasında önemli bir rol oynamaktadırlar. Ancak KOBİ'ler, krizlerin küresel finansal piyasaların üzerinde yarattığı ani ve şiddetli etkileri nedeniyle çeşitli sorunlarla karşı karşıya kalmaktadırlar. Bu anlamda Covid-19 pandemisi, iş dünyasını ve ekonomiyi etkileyen yeni bir tehdittir. Küresel boyutta devam etmekte olduğu için, yarattığı etkilerin boyutları henüz tam olarak ortaya konulamamıştır. Çalışmanın amacı, Covid-19 sürecinde KOBİ'lerin finansal görünümünü ortaya koyabilmektir. Bu amaç doğrultusunda Denizli İl'inde tekstil sektöründe faaliyet gösteren KOBİ yöneticileriyle görüşme yöntemi kullanılarak veri toplanmıştır. Sonuç olarak, Covid-19'un tekstil sektöründeki işletmelere etkisinin işletmenin faaliyet konusuna ve iş modeline göre farklılık gösterdiği, sipariş üzerine üretim yapan bazı tekstil işletmelerinin siparişlerinin pandemi sürecinde askıya alındığı veya iptal edildiği tespit edilmiştir. Bu durumun işletmelerin finansal görünümünde nakit, stoklar, ticari alacaklar, gelirler, borç / öz kaynak yapısı, gider ve maliyet kalemlerinin öne çıkmasına neden olduğu belirlenmiştir.

Anahtar Kelimeler: COVID-19, KOBİ, Finansal Görünüm

ABSTRACT: With their entrepreneurial activities, small and medium sized-enterprises (SMEs) play an important role in a country's socio-economic development. However, SMEs are faced with a variety of problems due to sudden and severe the impact of crises on global financial markets. The Covid-19 pandemic is a new threat affecting the business world and the economy. Since this pandemic continues global, the extent of the threat posed by Covid-19 has not yet been fully understood. The aim of this study is to reveal the financial outlook of SMEs during the Covid-19 crisis. For this purpose, data were collected by using the interview method with SME managers operating in the textile sector in Denizli province, Turkey. As a result, it has been determined that the effect of Covid-19 on businesses in the textile sector differs according to the field of activity and business model of the enterprise. The orders of some businesses producing textiles to order were suspended or canceled during the pandemic. It was determined that this situation has caused cash,

${ }^{1}$ Çalışma için Trakya Üniversitesi Sosyal ve Beşeri Bilimler Araştırmaları Etik Kurulu tarafindan 09.09.2020 tarihinde 06/16 karar numarası ile etik kurul onayı verilmiştir.

"Dr. Öğr. Üyesi, Trakya Üniversitesi, ilknureskin@ hotmail.com, ORCID: 0000-0003-23067315. 
stocks, trade receivables, revenues, the debt / equity structure, expenses and cost items to stand out in terms of the financial outlook of the enterprises.

Key Words: COVID-19, SMEs, Financial Outlook

\section{EXTENDED ABSTRACT}

SMEs generate the basis of economic and social stability in Turkey as well as in the world. Although SMEs have such an important role, they may be affected more by crises due to their weak financial structures compared to large-scale enterprises. The Covid-19 pandemic is a new threat affecting all sectors of the economy. Although the extent of COVID impacts is not fully revealed, it is predicted to have devastating consequences for SMEs. In this context, the aim of the research is to reveal the financial outlook of SMEs during the Covid-19 crisis.

Interview technique was chosen as the data collection method in the research. Online interviews were held with nine SME managers operating in the textile sector in Denizli Province. The reason for choosing Denizli Province in the research is the high concentration of small, medium and large scale enterprises in the textile sector. Managers were asked about the effects of Covid-19 on the operations of businesses and how it affects the financial outlook of businesses. Afterwards, the data obtained from the interview method were transformed into a written text and the procedure of coding, creating a theme, summarizing and interpreting was followed to include meaningful results (Turner, 2010: 759).

As a result of the findings obtained in the first part of the research; although the degree of exposure of the businesses from the crisis varies according to the activity of the businesses in the sector, it can be said that the first effect of the pandemic is on the orders of the businesses. While the pandemic did not adversely affect the technical textile, home textile and knitters group in the textile sector, it negatively affected the outerwear fabric manufacturers. As the demand for outerwear fabric manufacturers stopped, it caused the postponement and cancellation of both old and new orders. On the other hand, the business model that the enterprise uses to improve its activities has been effective in managing the crisis. It was determined that businesses that attach importance to e-commerce sales and start to produce antibacterial medical textile products and masks \& medical overalls turn the pandemic process into an opportunity. Also, although business managers have voiced the negative effects of the pandemic, few businesses have scientifically conducted a SWOT analysis.

In the second part of the research, it has been determined that the financial outlook of businesses changes according to their ability to manage the Covid-19 pandemic. The businesses that selling through e-commerce, producing antibacterial medical textile products, beginning produce masks and medical materials in the pandemic don't have financial problems. On the other hand, the global lockdown due to the pandemic has deeply affected many businesses. During the pandemic, 
the businesses do not have enough working capital because of the extension of the collection period of the receivables, the cancellation of the orders, the inability to make sales, the delay of the delivery of the customers and stock turnover problems. In order to solve this problem, businesses have obtained funds by obtaining loans from public banks and discounting checks and bills in their portfolio. As the working capital cycle was disrupted, the debt burden of the enterprises increased, thus the debt / equity ratio and this increased the financing costs. On the other hand, during this period the decrease in revenues and the increase in production costs arising from energy expenses leaded to the operating profit to melt. This will adversely affect the cash flow from the business's operations and cause the working capital problem to fall into a vicious circle. In this process, SMEs make strict budget controls by focusing on expense and cost items, and review the management of their commercial receivables in order to ensure their sustainability. Except for a few businesses, it has been determined that the pandemic does not cause changes in their business models. The most common action in this process is to continue marketing activities in the digital environment. In addition, it has been determined that the pandemic experience does not cause businesses to innovate, invest in digital, and review their supply chains. The results of the study confirm the results of the studies conducted on this subject (Lu et al., 2020; Cowling and Brown, 2020; Shafi, Liu and Ren 2020; Qamruzzaman; 2020; Thorgren and Williams, 2020; Omar et al., 2020).

As the dimensions of the Covid-19 pandemic change, the effects on businesses will also be different. Therefore, SMEs need guidance in order to be able to manage the global crisis and to be integrated into the process. At this point, it is important that the sector boards under the Chambers of Commerce and Industry work with the sector to reduce the effects of the global epidemic on business activities and to solve the problems encountered in financial management.

\section{GíRiş}

Günümüzde, KOBI'lerin ülke ekonomilerinde sahip olduğu oransal büyüklük bir yana, toplam istihdam, katma değer, yatırım, vergi, ihracat ve krediler içindeki paylarının da önemli boyutlara ulaştı̆̆ı görülmektedir. Türkiye'de KOBİ'ler toplam girişimlerin \%99,8'ini, istihdamın \%76'sını, katma değerin $\% 54$ 'ünü, yatırımların \%50'sini, üretimin \%56'sını, ihracatın \%60'ını gerçekleştirmektedir (TÜİK, 2015). Tekstil sektörü yan sanayi ve uluslararası tedarik zinciri ile birlikte çok sayıda işletmeyi birbirine bağlamaktadır. Tekstil sektörü, Türkiye'nin imalat sanayi üretim değeri toplamının \%8,8'ini ve imalat sanayinde yaratılan katma değerin \%9,9'unu sağlamaktadır (Uyanık ve Çeliker, 2019:33-35).

Ekonomide önemli rolleri olan KOBİ'ler kırılgan finansal yapıları nedeniyle Covid-19 krizinin tehdidi altındadır (Thorgren ve Williams, 2020:2). İşyerlerinin 
kapanması veya tedarikte yaşanan sıkıntılar büyük işletmelere oranla KOBİ'ler üzerinde daha büyük bir baskı oluşturmaktadır (Eğri ve Doğaner, 2020, s.129). Bu baskı finansal yapıları üzerinde önemli etkilere neden olmaktadır. İşletmeler; döviz kurundan kaynaklanan kayıplar yaşamakta, sermayeleri küçülmekte, stokları artmakta, tahsilat güçlüklerine bağlı olarak ticari alacakları şüpheli ve değersiz hale gelmekte, işçi çıkarımına bağlı olarak ödenen tazminatları artmakta ve ciddi zarar rakamlarıyla karşı karşıya kalmaktadır (Tuğay, Dalğar ve Tekşen 2014: 3).

Bu çalışmanın amacı, Covid-19 krizinde tekstil sektöründe faaliyet gösteren KOBİ'lerin finansal görünümünü belirlemektir. $\mathrm{Bu}$ amaç doğrultusunda Denizli Il'inde tekstil sektöründe yer alan KOBI'lerin yöneticileriyle görüşme yöntemi kullanılarak veri toplanmıştır. Literatürde, Covid-19'un KOBI'lere etkisini belirlemek amacıyla yapılan çalışmalar bulunmaktadır. Bu çalışmada ise, Covid19'un tekstil sektörüne, işletmelere, operasyonlara etkisinin finansal görünümünü nasıl etkilediğine odaklanılmıştır. Çalışmanın diğer bölümlerinde sırasıyla literatür incelemesi, Covid-19'un Türkiye ekonomisine ve KOBI'ler üzerine etkileri, araştırmanın metodolojisi, araştırmanın bulguları açıklanmıştır. Sonuç bölümünde ise araştırmadan elde edilen bulgular değerlendirilmiştir.

\section{LITERATÜR}

Krizlerin KOBİler üzerindeki etkilerini araştıran birçok çalışma bulunmaktadır. Eggers'e (2020) göre, KOBİ'lerin kriz döneminde finansal yönlerini inceleyen çalışmalar literatürün \%50,7'sini oluşturmaktadır. KOBI'lerin istihdam yaratma, yenilikçilik ve ekonomik büyümedeki önemi göz önüne alındığında, birçok araştırmaya konu olmaları normaldir.

Apak, Erol ve Atmaca (2012), Türkiye'deki KOBİ'lerin kriz dönemlerinde maliyet tasarrufu sağlayan, nakit akışını hızlandıran tedbir ve savunma stratejilerine önem verdiklerini belirlemişlerdir. Proença, Laureano ve Laureano (2014), Portekiz'deki KOBI'lerin 2007-2010 dönemini inceledikleri çalışmada, finansal kriz sırasında dış finansman maliyetinin yüksek olması nedeniyle işletmelerin borç oranının düştügünü belirlemişlerdir. He ve Ausloss (2017), Çin'deki KOBI'lerin \% 20'den fazlasının kriz döneminde iflas ettiğini ve geri kalan işletmelerin ise ciddi sermaye sıkıntısı yaşadığını tespit etmişlerdir.

Yazdanfar ve Öhman (2019), İsveç’teki KOBİ'lerin 2008-2015 dönemlerini incelemişler, işletmelerin finansal sıkıntılarının küresel finansal kriz gibi makroekonomik koşullardan ve özellikle işletmeye özgü unsurlardan (önceki dönem performans, finansal kaldıraç ve finansal sorunlar) kaynaklandığını belirlemişlerdir. Zubair, Kabir ve Huang (2020), Hollanda'daki KOBİ'lerin kriz dönemini (2008-2009) ve kriz sonrası dönemini (2010-2012) inceledikleri çalışmada, işletmelerin her iki dönemde de yatırımlarının azaldığını, kriz döneminde işletme yatırımlarında banka finansmanının kritik rol oynadığını, kriz 
Aralık 2021 Cilt 23 Sayı 2 (571-592)

sonrası dönemde ise yatırımlarda hem iç hem de dış finansmanın etkili olduğunu tespit etmişlerdir.

Covid-19'un 2020 yılında küresel bir salgın haline gelmesi ile birlikte literatürde Covid-19'un işletmelere etkisini ortaya koyan çalışmalar yoğunlaşmıştır. Kottika vd.,(2020), ekonomik krizde işletmelerin dış pazar imkânlarını keşfetme firsatına sahip olmalarına rağmen, Covid-19 döneminde uluslararası pazar bulma imkânlarının çok zor olacağını belirtmişlerdir. Çalışmada, pazar odaklı ve girişimcilik oryantasyonu yaklaşımlarının KOBI'lerin Covid-19 krizinde etkili bir şekilde rekabet edebilmelerinde önemli olacağı ve bunların işletmelerin performanslarını arttıracağı vurgulanmıştır.

Lu vd., (2020), pandemi döneminde Çin'deki KOBİ'lerin ücret, kira, vergi gibi sabit giderleri üstlenmek zorunda kaldıkları için nakit akışında sorun yaşadıklarını, yeni sipariş alamadıklarını, mal ve hizmet satışı yapamadıkları için gelir kaybettiklerini belirlemiş̧erdir.

Cowling ve Brown (2020), Covid-19 pandemisinde İngiltere'deki KOBİ'lerin sadece \% 39'unun nakit dengelerini güçlendirdiğini ve bu durumda işletmelerin \% 61'inin nakit sıkıntısı yaşayabileceğini, özellikle mikro işletmelerin risk altında olduğunu tespit etmişlerdir.

Shafi, Liu ve Ren (2020), Pakistan'daki KOBİ'lerin pandemi sürecinde tedarik zincirinde aksama, satışların düşmesi ve kârların azalması gibi sorunlarla karşılaştı̆̆ını tespit etmişlerdir. Çalışmada işletmelerin bu sorunlarla başa çıkmak için bankalardan kredi alma, işletmeyi kısmen veya tamamen kapatma ve maliyetleri düşürme gibi stratejiler benimsediği belirtilmiştir.

Omar, Ishak ve Jusoh (2020),Covid-19'un Malezya'daki KOBİ'lerde operasyonel (üretimin durmas1, tedarik zincirinin bozulması) ve finansal (nakit akışı sorunu, iflas riski) sorunları ortaya çıardığını ve işletmelerin sürdürülebilirliğini sağlamada finans \& pazarlama stratejilerinin etkili olduğunu belirtmişlerdir. Diğer ifadeyle, pandeminin yarattığı krizin etkisinin, işletmenin finansal kaynaklarının gücü ve yeni iş firsatları yaratma yeteneği ile ilişkili olduğu vurgulanmıştır.

Juergensen, Guimon ve Narula (2020), Avrupa'daki birçok KOBI'nin pandemi nedeniyle kısa vadede talebin durmasının yanı sıra lojistik zorluklarla karşı karşıya kaldığını belirtmişlerdir. Bu süreçte KOBI'lerin maliyetlerini düşürmeleri, verimliliklerini artırmak için üretim süreçlerini iyileştirmeleri ve dijital altyapılarını oluşturarak çevrimiçi satış uygulamalarına başlamaları önerilmiştir. Kraus vd., (2020) Covid-19'un oluşturduğu krizin işletmelerin iş modellerinde stratejik değişikliklere ittiğini ve dijital araçların operasyonlarda kullanımının zorunlu hale geldiğini belirtmişlerdir.

Zimon ve Dankiewicz (2020) Covid-19 sürecinde Polonya'daki KOBİ'lerin hammadde tedarik sıkıntısından korktukları için yüksek düzeyde stoklama 
yaptıklarını, alacaklarını sıkı bir şekilde kontrol ettiklerini ve mümkün olduğunca peşin satış yaptıklarını, uzun vadeli satışların oldukça sınırlı olduğunu, sadece stratejik müşterilerine aynı pozisyonda ticari kredi imkânları tanıdıklarını belirlemişlerdir. Qamruzzaman (2020) Bangladeş'teki KOBI'ler üzerine yaptığı araştırmada, işletmelerin pandemi nedeniyle satış yapamadıklarını ve bu nedenle yüksek stoklamanın getirdiği ek maliyete katlanmak zorunda kaldığını, işçi ücretlerini düşürdüklerini veya işçi çıkardıklarını, vadesi gelen kredi taksitlerini ödemekte zorlandıklarını tespit etmiştir. İsveç'teki KOBİ'ler üzerine bu konuda yapılan bir başka çalışmada (Thorgren ve Williams 2020), pandemi sürecinde KOBI'lerin yatırımlarını erteleme, işçi çıkarma, işgücü maliyetlerini ve giderlerini düşürme, banka ve firmalarla görüşerek ödeme koşullarını gevşetme, stoklarını azaltma gibi bir dizi acil eylem planını hayata geçirdikleri belirlenmiştir. Çalışmada, bu eylem planlarının odak noktasının negatif nakit akışını azaltmaya ve maliyetleri düşürmeye yönelik adımlar olduğu belirtilmiştir.

\section{COVID- 19'UN TÜRKIYYE EKONOMISINE VE KOBI'LER ÜZERINNE ETKILERI}

Küresel bir sağlık krizi olan Covid-19 salgını, 1930'lardaki Büyük Burhan'dan bu yana en derin ekonomik durgunluğu yarattı. 2020 yılında küresel ekonomik faaliyetlerde $\% 6$, gayri safi yurtiçi hasılada $\% 20$ 'den fazla düşüş yaşandı, OECD'de işsizlik düzeyi \% 9,2'ye yükseldi (OECD a, 2020). McKinsey Global Enstitü tarafindan yapılan araştırmada, küresel ticaret talebinin 2020'nin ikinci ve üçüncü çeyreğinde yüzde 13 ile 22 arasında düşeceği tahmin edilmektedir. 2008 yılında yaşanan küresel finansal krizde ticaret hacimlerindeki en büyük üç aylık düşüş ise yüzde 5 civarındaydı. Bu oran ile kıyaslandığında Covid-19 pandemisinin yarattığ belirsizlik 2008-2009 krizinin etkilerinden daha derin olacağı tahmin edilmektedir. Salgının yayılmasını yavaşlatmak için getirilen hareket ve fiziksel mesafe kısıtlamaları, işgücü arzını, ulaşımı ve seyahati doğrudan etkilemiş olup oteller, restoranlar, zaruri olmayan perakende ticaret, turizm ve önemli üretim alanları dâhil olmak üzere tüm sektörlerde üretim durmuştur. Çin'de ortaya çıkan salgının yayılmasını kontrol altına almak amacıyla büyük üretim merkezleri kapatılmıştır. Çin'in bir üretim üssü olması nedeniyle ilaçtan otomobile kadar tüm sektörleri etkileyen küresel tedarik zinciri işleyişinin durması, üretim yapan dünya ekonomilerinde yavaşlamaya neden olmuştur (WTO, 2020).

Dünya ekonomileri küçülürken Türkiye ekonomisinin küçülmesi kaçınılmaz görülmektedir. Pandemi döneminde üretim azalmış, yatırım kararları ertelenmiş ve bu gelişmeler sonucunda talep düşmüştür. Üretimin azalması beraberinde işsizlik sorunu, harcanabilir gelir düşüklüğü ve talebin azalması gibi sorunları getirmiştir. İşletme tasarruflarının etkilenmesiyle birlikte Covid-19'un ekonomik etkisinin çok daha derin olacağı tahmin edilmektedir (TÜRMOB, 2020: 44). Pandeminin ülke ekonomisine etkilerini dış ticaret verileri ortaya koymaktadır. Bu verilere göre; 
ihracat 2020 yılı Ocak-Haziran döneminde bir önceki yılın aynı dönemine kıyasla $\% 15,1$ azalarak 75 milyar 21 milyon dolar olup ithalat ise \%3,2 azalarak 98 milyar 895 milyon dolar olarak gerçekleşmiştir (TÜİK, 2020).

Finansal sektörde ise, güven ortamının azalması, ödeme akışlarının bozulması ve firmaların nakit tercihlerinin artması söz konusudur. Devletlerin likidite sorunu ile karşılaşmamak için uyguladıkları para politikaları olsa da, özellikle KOBİ'lerin kredi kanallarına erişim sorunları onları krize karşı daha duyarlı hale getirmektedir (Eğri ve Doğaner, 2020:133). Ayrıca, Covid-19'un KOBİ'lerin faaliyetlerine olumsuz etkisi nedeniyle işletmeler, faaliyetlerini durdurma, işçi çıkarma, personel sayısını azaltma ve kapasite düşürme gibi hayati zorluklarla karşı karşıyadır. Ancak bu zorluklar, işletmelerin bulunduğu sektöre göre farklılık göstermektedir (Omar, Ishak ve Jusoh, 2020:141).

Türkiye'de KOBİlere yönelik gerçekleştirilen “COVID-19 Krizinin İşletmeler Üzerindeki Etkileri" araştırması yukarıdaki açıklamaları doğrulamaktadır (TÜRKONFED, 2020). Ankete katılan 780 işletmenin \% 78'i pandemi krizinden etkilendiklerini belirtmiştir. Krizden en yoğun etkilenen işletmeler \% 69 ile mikro işletmeler, \% 49 ile küçük ölçekli işletmeler, \%38 ile orta büyüklükte işletmelerdir. Araştırma; işletmelerin cirolarının azaldığını, tedarik zincirinde sıkıntı yaşadıklarını, borçlarını ödemekte zorlandıklarını, personel sayısını azaltma kararı aldıklarını göstermektedir. Ayrıca, araştırmada, işletmelerin \% 59'unun ikinci dalga Covid-19 salgınına hazır olmadığ 1 görülmektedir. Öte yandan son araştırmalara göre KOBİ'lerin Covid-19'a duyarlılığ Mayıs ayına göre biraz daha iyimser hale gelmiştir. Bunun en önemli nedeni işletmelerin kontrollü normalleşme sürecinde faaliyetlerine devam etmeleridir. Örneğin ABD'de küçük işletmelerin çoğunluğu (\%82) Covid-19'un etkisinden endişe duymaktadır. Ancak, Mayıs ayında \%53 olan "çok endişeli" işletmelerin payı Haziran ayında \% 43'e düşmektedir. $\mathrm{Bu}$ dönemde işletmelerin \% 56'sı nakit akışı durumlarıyla ilgili olarak kendilerini rahat hissettiğini ifade etmiştir (OECD b,2020).

\section{ARAŞTIRMA YÖNTEMI}

Çalışmanın bu bölümünde yapılan araştırmanın amacı, yöntemi, evren ve örneklem bilgisi açıklanmıştır.

\subsection{Araştırmanın Amacı}

Araştırmanın amacı, Covid-19 sürecinde KOBİlerin finansal görünümünü ortaya koyabilmektir. Bunun için, etkilerin neler olduğunu ve işletmeleri nasıl etkilediğini bilmek önemlidir. Bu nedenle araştırmanın ilk bölümünde Covid-19'un tekstil sektöründe faaliyet gösteren işletmelere ve bunların operasyonlarına etkisi incelenmiştir. İkinci bölümde ise, işletmenin finansal görünümü etkileyen unsurlar incelenmiştir. 


\subsection{Araştırmanın Yöntemi}

Araştırmanın amacı doğrultusunda veri toplamak için nitel araştırma yöntemlerinden görüşme tekniği seçilmiştir. Görüşme yöntemi, bireylerin görüş, deneyim ve duygularını ortaya çıkarması açısından oldukça güçlü bir veri toplama yöntemidir. Görüşme yönteminde güvenilir veri toplanması için, görüşme formunun hazırlanması, test edilmesi, görüşmelerin ayarlanması, hazırlıkların yapılması ve görüşmelerin gerçekleştirilmesi gerekir (Yıldırım ve Şimşek, 2016:136).

Araştırmada, görüşme yönteminde belirlenen adımlar dikkate alınmıştır. Öncelikle görüşme formundaki sorular literatür dikkate alınarak hazırlanmış, ardından bu soruların eksiklik, sınırlama ve zayıflıkların olup olmadığını belirlemek için bir KOBİ uzmanı (Yeminli Mali Müşavir) üzerinde pilot test yapılmıştır. $\mathrm{Bu}$ soruların araştırmanın amacına uygun olduğu anlaşıldıktan sonra görüşme formu netleşmiştir.

Görüşme Soruları Ek 1'de sunulmuştur.

\subsection{Araştırmanın Evren ve Örneklemi}

Araştırmanın çeşitli sınırlılıkları nedeniyle Denizli İl'inde faaliyet gösteren KOBİ kapsamındaki tekstil işletmeleri seçilmiştir. Araştırmada Denizli İl'inin seçilmesinin nedeni tekstil sektöründe küçük, orta ve büyük ölçekli işletmelerin yoğunlukta olmasıdır. Örneklem sayısının belirlenmesinde ise, ulaşılması istenen bilginin veri tarafından tekrarlanmaya başlamasına dikkat edilmiştir. Belirlenen kriterlerde seçilen örneklem ile yapılan görüşmelerde sekizinci görüşmeden itibaren verinin tekrarlandığı gözlemlendiği için, dokuzuncu görüşmede örneklem sayısı tamamlanmıştır. Covid-19 bulaş riski nedeniyle 20 Ağustos - 31 Ağustos 2020 tarihleri arasında Denizli'de 9 yönetici ile online görüşme yapılmıştır. Görüşmelerin her biri yaklaşık 50 dakika sürmüştür.

\subsection{Verilerin Analizi}

Araştırma verilerinin analizi için katılımcıların izni alınarak görüşmelerin kaydı alınmıştır. Görüşme yönteminden elde edilen veriler yazılı metne dönüştürülmüş ve anlamlı sonuçlar içermesi için kodlama, temalandırma, özetleme ve yorumlama prosedürü izlenmiştir (Turner,2010: 759).

\section{ARAŞTIRMANIN BULGULARI}

Çalışmanın bu bölümde araştırma verilerinden elde edilen bulgular açıklanmıştır.

\subsection{Genel Bilgiler}

Görüşme yapılan kişilerin ve işletmelerin bilgileri Tablo 2'de yer almaktadır. Görüşme yapılan yöneticilerin ismi etik kurallar gereği örtüldügü için, yöneticiler "G1", "G2" vb. gibi kodlanmıştır. 
Aralık 2021 Cilt 23 Sayı 2 (571-592)

Tablo 1: Görüşmecilerin ve İşletmelerin Bilgileri

\begin{tabular}{|c|c|c|c|c|c|c|}
\hline Görüșmeci & Unvan & \begin{tabular}{|l|} 
İş \\
Deneyimi
\end{tabular} & Eğitimi & $\begin{array}{l}\text { Sirketin } \\
\text { Ünvanı }\end{array}$ & $\begin{array}{l}\text { Faaliyet } \\
\text { Konusu }\end{array}$ & $\begin{array}{l}\text { İșci } \\
\text { Sayısı }\end{array}$ \\
\hline G 1 & $\begin{array}{l}\text { Şirket } \\
\text { müdürü }\end{array}$ & $30 \mathrm{y} 1$ & Lisans & $\begin{array}{l}\text { Limited } \\
\text { Şirket }\end{array}$ & Dokuma & 13 \\
\hline G2 & $\begin{array}{l}\text { Genel } \\
\text { Müdür }\end{array}$ & $15 \mathrm{y} 1$ & Lisans & $\begin{array}{l}\text { Limited } \\
\text { Şirket }\end{array}$ & $\begin{array}{l}\text { Giyim } \\
\text { üretimi }\end{array}$ & 100 \\
\hline G3 & $\begin{array}{l}\text { Yönetim } \\
\text { Kurulu } \\
\text { Başkanı }\end{array}$ & $30 \mathrm{y} 1$ & Lisans & $\begin{array}{l}\text { Limited } \\
\text { Şirket }\end{array}$ & $\begin{array}{l}\text { Kumaş } \\
\text { üretimi }\end{array}$ & 150 \\
\hline G4 & $\begin{array}{l}\text { Şirket } \\
\text { Müdürüi }\end{array}$ & $24 \mathrm{y} 1$ & Lisans & $\begin{array}{l}\text { Limited } \\
\text { Şirket }\end{array}$ & Ev tekstili & 20 \\
\hline G5 & $\begin{array}{l}\text { Şirket } \\
\text { Müdürü }\end{array}$ & $15 \mathrm{y} 1$ & $\begin{array}{l}\text { Yüksek } \\
\text { Lisans }\end{array}$ & $\begin{array}{l}\text { Anonim } \\
\text { Şirket }\end{array}$ & $\begin{array}{ll}\text { Iplik } & \text { ve } \\
\text { kumaş } & \\
\text { üretimi } & \\
\end{array}$ & 200 \\
\hline G6 & $\begin{array}{l}\text { Şirket } \\
\text { Müdürü }\end{array}$ & $23 \mathrm{y} 11$ & Lisans & $\begin{array}{l}\text { Limited } \\
\text { Şirket }\end{array}$ & $\begin{array}{l}\text { Otel Tekstil } \\
\text { üretimi }\end{array}$ & 157 \\
\hline G7 & $\begin{array}{l}\text { Genel } \\
\text { Müdür }\end{array}$ & $15 \mathrm{y} 1$ & Lisans & $\begin{array}{l}\text { Limited } \\
\text { Şirket }\end{array}$ & $\begin{array}{l}\text { Kumaş } \\
\text { üretimi }\end{array}$ & 80 \\
\hline G8 & $\begin{array}{l}\text { Şirket } \\
\text { Müdürü }\end{array}$ & $25 \mathrm{y} 1$ & Lisans & $\begin{array}{l}\text { Limited } \\
\text { Şirket }\end{array}$ & 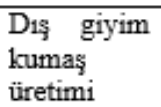 & 25 \\
\hline G9 & $\begin{array}{l}\text { Yönetim } \\
\text { Kurulu } \\
\text { Başkanı }\end{array}$ & $50 \mathrm{y} 1$ & Lisans & $\begin{array}{l}\text { Anonim } \\
\text { Şirket }\end{array}$ & 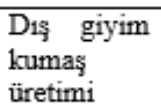 & 125 \\
\hline
\end{tabular}

Tablo-1 incelendiğinde; görüşülen kişilerin beşi şirket müdürü, ikisi genel müdür ve ikisi yönetim kurulu başkanıdır. Görüşmecilerin iş deneyimi 15 ila 50 yıl arasındadır ve eğitim düzeyi ağırlıklı olarak lisans düzeyindedir. İşletmelerin hukuki yapısını incelediğimizde ağılıklı olarak limited şirket oldukları görülmektedir. İşletmelerin faaliyet alanı, tekstil sektörünün alt sektörleri olan iplik, dokuma, kumaş, giyim, ev ve otel tekstil ürünlerinin üretimidir. İşletmelerde çalışan personel sayısı 13 ile 200 arasında değişmektedir.

\subsection{Covid-19 Pandemisinin Tekstil Sektörüne, İşletmelere ve Operasyonlara Etkisine İlişsin Bulgular}

Sektöre ve İsletmeye Etkileri

Görüşülen kişilerin çoğu yoğunluklu olarak Avrupa pazarına mal sattıklarını ifade etmişlerdir. Çin'de Covid-19 vakalarının görüldüğü dönemde Avrupalı müşterilerinin uzak doğu pazarından Türkiye pazarına kaydığını, Ocak- Şubat aylarında hem Avrupa pazarına hem de iç pazara çalıştıklarını belirtmişlerdir. Mart ayında Türkiye'de Covid-19 vakalarının görülmesi, Avrupa'da salgının artması nedeniyle yerli ve yabancı müşterilerin üretimini kısmen ve tamamen durdurduğunu ve Mart-Nisan aylarında siparişlerin askıya alındığını veya iptal edildiğini eklemişlerdir. Ayrıca, tekstil sektöründe yer alan teknik tekstil grubu (medikal, hijyen, filtre vb. üretimi), ev tekstili grubu (havlu, bornoz, çarşaf vb. 
üretimi) ile örmeciler grubunun (tişört, eşofman gibi ev giyimi üretimi) pandemi döneminde olumsuz etkilenmediklerini, hatta bu dönemde üretimlerini arttırdıklarını belirtmişlerdir. Görüşmeci 3 şu yorumu yaptı:

"Avrupalı müşterilerimiz Covid-19 vakalarının başladı̆̆ dönemde uzak doğu pazarından Türkiye'ye kaydl. Dolayıslyla Mart ayına kadar sektörde sıkıntı yaşanmadi. Pandemi sorunu ülkemizde de başlamastyla ev tekstili, teknik tekstil ve örmeciler üreticileri dışında kalan işletmeler talebin durması nedeniyle sorunlar yaşadılar. Biz hem dış giyim hem de ev tekstil grubuna çalıştığımız için riski dăglttık."

Görüşmeci 8 ve 9 şu açıklamaları yaptı:

“Covid-19 vakalarinın Uzakdoğu’da görüldüğ̈̈ dönemde Türk tekstil işletmeleri hem iç piyasaya hem de dlş piyasaya çalışıyordu. Özellikle Avrupalı müşterilerimiz bizi tercih ediyordu. Ancak Mart ayında ülkemizde de pandemi krizinin başlaması sektörde faaliyetlerin durmasına neden oldu. Satışlarımızın büyük bölümü yurtdlşı pazar olmasindan dolayı işletme faaliyetlerimizi 2 ay durdurduk. Halâ tam kapasiteyle çalışamıyoruz, aylı \%50 üretim kaybımız var."

"Pandemi döneminde tekstil grubunda yer alan teknik, ev tekstili ve örmeciler grubu olumsuz etkilenmedi, ancak bizim işletmemiz gibi diş giyim kumaş üretimi yapan işletmeler bu süreçten olumsuz etkilendi. İşletmemizin üretim kapasitesi \% 60 oranında azald ve buna bağlı olarak mali sorunlar yaşadık".

Görüşülen kişilerin çoğu pandeminin ilk etkisinin siparişler üzerinde olduğunu, siparişlerin askıya alınması ve iptali nedeniyle Mart ayında yarı kapasitede çalıştıklarını, Nisan ayında üretimi durdurmak zorunda kaldıklarını belirtmişlerdir. Mayıs ayında üretime devam ettiklerini, ancak siparişlerin istenilen seviyeye gelmemesi nedeniyle kapasite kullanım oranlarının ortalama \% 40-50 düzeyinde olduğunu eklemişlerdir. Görüşmeci 6 şu yorumu yaptı:

"İsletmemizin müssteri portföyünü ağırlıkl olarak otel ve restoran işletmeleri oluşturduğu için, üretimimiz otel tekstil ürünlerine yöneliktir (havlu, bornoz ürünleri). Pandemi döneminde özellikle Nisan, Mayls aylarında hizmet verdiğimiz sektördeki işletmelerin kapanması nedeniyle siparişlerimizin tamamı iptal edildi. Üretim kapasiteminiz \% 70 oraninda düştü."

Ancak, ev tekstil ürünleri üreten şirket yetkilisi (Görüşmeci 4) pandemi döneminden önce e-ticarete başladıkları için pandemi döneminde ürünlerine olan talebin arttığını ve bu sürecin işletmenin faaliyetlerini olumsuz etkilemediğini belirtmiştir.

İşletme Operasyonlarına Etkileri

Görüşülen kişilerin çoğu pazarlama faaliyetlerini pandemi döneminde dijital ortamda yapmaya başladıklarını ve bunu dijital dönüşümün başlangıç adımı olarak gördüklerini belirtmişlerdir. Görüşmeci 4 ve 8 bu konuda şunları ifade etmiştir: 
"Uluslararası kumaş fuarlarının iptal edilmesi nedeniyle birçok müşsterimizle buluşamadık, bu nedenle koleksiyonumuzu online fuar sistemi, elektronik katalog ve diğer dijital operasyonlarla sunmaya başladık".

"Yakın zamanda satış operasyonlarını dijital ortamda yürütmeyi planlıyoruz."

Görüşmeci 1, pandemi döneminde likidite sorunu yaşadıkları için çalışma sermayesinin yönetimi konusunda önemli kararlar aldıklarını belirtmiştir. Özellikle stokların, alacakların ve borçların yönetiminde disiplinli davranmaya başladıklarını eklemiştir. Görüşmeci 6 ise, pandemi nedeniyle yatırım planlarını durdurduklarını, makine yenileme projelerini iptal ettiklerini ifade etmiştir.

\section{SWOT Analizi}

İşletmeler kriz öncesi ve sonrasında SWOT analizi ile güçlü yönlerini, zayıf yönlerini, fırsat ve tehditlerini değerlendirebilir (Apak vd., 2012) ve analiz sonucunda stratejiler geliştirebilir. Görüşmeci 1,5,6 ve 7 bu süreçte genel olarak işletmelerinin değerlendirilmesini yaptıklarını, ancak SWOT analizi yapmadıklarını belirtmiştir.

Görüşmecilerden bazıları bu süreçte sadece firsatları değerlendirdiklerini belirtmişlerdir. Görüşmeci 3, bu süreçte ar-ge faaliyetlerine odaklandıklarını, anti bakteriyel medikal tekstil ürünleri geliştirdiklerini ve üretime başladıklarını ifade etmiştir. Görüşmeci 4, pandemi öncesi dijital yatırımlarının yapılması sonucunda eticaret satışlarına ağırlık verdiklerini belirtmiştir. Görüşmeci 2 ise, bu konudaki düşüncesini şöyle ifade etti:

"İ̧̧letmemiz yurtdışı pazara yönelik gömleklik kumaş üretimi yapmaktadır. Pandemi döneminde işletmemizin ayakta kalabilmesi için birçok alternatif düşündük ve maske, tıbbi tulum üretmeye karar verdik. Daha önce çalışmadığımız pazara girmek zorunda kaldık."

Görüşmeci 8 ve 9 işletmelerinin güçlü ve zayıf yönlerinin yanı sıra firsatları ve tehditleri değerlendiklerini ifade etmiştir. Görüşmeci 9 şu yorumu yaptı:

"Kaliteli kumaşlar üretmemiz ve Avrupa pazarını bilmemiz bizim güçlü yönlerimizdir. Bu süreçte dijital pazarlamanın getirdiği maliyet avantajından yararlanarak firsatları yakalamayı hedefliyoruz. Ancak enerji, işçilik giderlerinin yüksek olması, döviz kurlarının artışından kaynaklanan hammadde maliyetlerinin artması sonucu üretim maliyetlerimizin artması bizim uluslararası pazarlarda fiyat avantajından yararlanmamızı engelliyor."

\subsection{Finansal Görünüme İlişkin Bulgular}

\section{Stoklar}

Görüştüğümüz kişiler, işletmelerinin sipariş üzerine üretim yaptığını belirtmişlerdir. Ev tekstil üreticisi Görüşmeci 4, pandemi döneminde depolarında yeterli hammadde stokları olduğu için üretime devam ettiklerini ve ürettikleri ürünleri e-ticaret kanalıyla satış yaptıklarını belirtmiştir. Görüşmeci 2, müşterilerinin fabrikalarını kapatmalarından dolayı sipariş üzerine ürettikleri 
kumaş stoklarını teslim edemediklerini, ancak maske ve tıbbi tulumların stok devir hızında bir sorun yaşamadıklarını belirtmiştir. Bazı görüşmeciler ise, sipariş üzerine ürettikleri ürünleri müşterilere teslim edemediklerinden dolayı depolama maliyetlerine katlanmak zorunda kaldıklarını ifade etmiştir. Görüşmeci 5 ve 7 bu durumu şu şekilde açıklamıştır:

"Müssterilerimize teslimat için ek süreler vermek zorunda kaldık, ek depo alanları ve atıl alanları kullanılabilir depolara dönüştürdük ve sipariş üzerine üretilen malları buralarda muhafaza ettik. Mayls ayında mal sevkiyatına başladık, ancak Temmuz ayında bile siparişlerini teslim almak istemeyen işletmeler vard. Bu durum stok maliyetine (depolama) katlanmamiza neden oluyor."

“Avrupa'da ve ülkemizde sokağa çıkma yasaklarının başlamaslyla birlikte talep aniden durdu. Önceki aylarda aldlğımı siparişleri de teslim edemedik, müşterilere teslimat için ek süre vermek zorunda kaldık."

Alacaklar

Görüşmecilerin çoğu mallarını hem yurtiçi pazara hem de yurtdışı pazara sattıklarını, pandemi döneminde ihracat yaptıkları malların alacaklarını tahsil etmekte genel olarak herhangi bir sorun yaşamadıklarını, riskli alacaklarını Türk Eximbank'ın alacak sigortası uygulamasını kullandıkları için tahsil edebildiklerini belirtmiştir. Ancak yurtiçi ticarette yoğun olarak kullandıkları vadeli çek ve senet alacaklarını vade tarihinde tahsil edemediklerini, müşterilerinin vade uzatma konusunda uzlaşma taleplerini karşılamak zorunda kaldıklarını ve bu durumun likidite sorunu yarattığını ifade etmişlerdir. Bunlara ek olarak, yurtiçinde alacaklarını tahsil edememe risklerinin devam ettiğini ve bu sorunlar nedeniyle stratejik müşteriler dışındaki müşterilerle nakit veya kısa vadeli olarak çalışma kararı aldıklarını belirmişlerdir. Görüşmeci 7 şöyle yorum yapmıştır:

"Yurt dışı alacaklarımız için, Türk Eximbank'ın kredi sigortası uygulamasını kullandığımız için bu alacaklarla ilgili herhangi bir sorun yaşamadık. Ancak, yurtiçi müşterilerimize tahsilat için ek süre vermek zorunda kaldık. Bu süreç bize stratejik müşteriler dışında kalan müşterilerle kısa vadeli veya nakit olarak çalışmamız gerektiğini ögretti."

Yukarıdaki açıklamalara ek olarak Görüşmeci 4, e-ticaret kanalıyla da satış yaptığını ve bu satışların tahsilatında sorun yaşamadığını belirtmiştir. Görüşmesi 5 ise, pandeminin yarattı̆g belirsizliğin işletme alacaklarına etkisini şu şekilde açıklamıştır:

"Yurtiçi müşterilerimizin talepleri doğrultusunda ek süre vermek zorunda kaldık, pandeminin yarattığ belirsizlik ticari hayatı olumsuz etkilemesinden dolayl alacaklarımızı tahsil etme sorunu yaşıyoruz."

Görüşmeci 1 ve 6 sadece yurtiçi pazara mallarını sattıkları için, bu süreçte alacaklarını tahsil etme riski yaşadıklarını ve bu durumun sabit giderlerini ödemede sıkıntılar yarattığını belirtmiştir. Görüşmeci 1, bu konudaki görüşlerini şöyle açıklamıştır: 
"Işletmemiz küçük bir işletme olduğu için, ticari faaliyetlerimizi çek ve senetle yürütüyoruz. Pandemi döneminde müşteri firmalarımız işletmelerini kapattılar ve ciddi finansal sorunlar yaşadılar. Bu durumda bize olan borçlarını vadesinde ödeyemedikleri için vade tarihini uzatmak zorunda kaldık. Bu defa biz sabit giderlerimizi ödemede zorluk yaşadık ve bankalardan kredi aldığımı için biz borçlandık."

Borçlar

Görüşmeci 2,3,8 k1sa vadeli ticari ve mali borçlarını ödeyebilmek için pandemi sürecinde KOBI'lere özel hazırlanan destek paketlerinden yararlandıklarını, uzun vadeli borçlarını yapılandırmak amacıyla bir girişimlerinin olmadığını belirtmiştir. Görüşmeci 2 şu yorumu yapmıştır:

"Önceliğimiz kusa vadeli borçların ödenmesi olduğu için, kamu ve özel bankaların KOBI destek paketlerinde yer alan işletme kredilerinden yararlandık. Uzun vadeli borçlarımız için bir şey yapmadık."

Diğer görüşmeciler $(1,4,5,6,7,9)$, öncelikle bankalara olan borçlarını ödediklerini, ticari borçları için tedarikçi işletmelerden yeniden yapılandırma talep ettiklerini ve bu borçların vadelerinin 2-3 ay uzatıldı̆̆ını ifade etmişlerdir. Görüşmeci 7 şu yorumu yaptı:

"Ĕ̆er pandemi sürecinde bankaya olan borcumuzu ödeyemeseydik, ileriki bir dönemde ticari krediye ihtiyaç duyduğumuzda bunu almamız çok zor olacaktı. Bu nedenle öncelikle bankalara olan borçlarımızı ödedik, tedarikçi firmalarla iletişim kurarak ödeme için ek süre talep ettik. Bu dönemde borçlarımızı ödemek için işletmeye kayıtlı bazı gayrimenkulleri satmak zorunda kaldık."

Finansman Sorunları

Türkiye'de KOBI'lerin sorunları konusunda yapılan uygulamalı çalışmalarda, finansman sorunu genel olarak sorunlar listesinin ilk sıralarında yer almaktadır. Bu çalışmalarda KOBİ'lerin finansal sorunlarının kaynağı olarak kredi maliyetlerinin yüksek olması, işletme sermayesinin ve özkaynak sermayesinin yetersizliği, sermaye piyasasında fon elde etmede yaşadığı sorunlar vurgulanmıştır (Demir, Aydın ve Sezgin, 2019:227). Yöneticilerle yapılan görüşmelerde görülmektedir ki, işletme sermayesinin yetersizliği finansman sorunlarının ana kaynağıdır. $\mathrm{Bu}$ dönemdeki finansman sorunları kamu bankalarından alınan kredilerle çözülmüştür. Görüşmeci 1, bu konudaki yorumumuzu kanıtlamıştır:

"Nakit dönüş sürelerin uzaması nedeniyle finansman sorunları yaşadık. Bu sorunumuzu şirket ortaklarından borç alarak, portföyümüzdeki çek ve senetleri vadesinden önce tahsil etmek amacıyla bankaya iskonto işlemi yaptırarak ve bankadan kredi alarak aşmaya çalıştık."

Görüşmeci 3,4,8 ve 9 ise, bu süreçte ciddi boyutta finansal sorunlar yaşamadıklarını, acil fon kaynağına ihtiyaç duyduklarında banka kredisi kullandıklarını belirtmiştir. 
Çalışma Sermayesi

Çalışma sermaye yönetimi; işletmelerin üretimini kesintisiz biçimde devam etmeleri, borçlarını zamanında ödemeleri, kriz dönemlerinde yaşanan dalgalanmalardan etkilenmeden faaliyetlerini sürdürmeleri, hedeflerine başarılı şekilde ulaşmaları gibi işlevleri yerine getirmelerinde kritik rol oynamaktadır (Atmaca, 2016: 636). Görüşmelerimiz, pandemi döneminde işletmelerin çalışma sermayesi bileşenlerinden kaynaklanan sorunlar nedeniyle çalışma sermayesi yönetiminde zorluklar yaşadıklarını gösterdi. Bu sorunlar; alacakların tahsilat süresinin uzaması, siparişlerin iptali nedeniyle üretimin durması ve buna bağlı olarak satış yapılamaması, müşterilerinin teslimatı iptal veya ötelemelerinden dolayı mamul stoklarının ellerinden çıkaramamaları ve kısa vadeli borçların ödenmesinde yaşanan sorunlardır. Görüşmeci 6 , bu konudaki yorumumuzu kanıtlamıştır:

"Müşterileri portföyümüzün \%95'ini otel ve restoranlar oluşturmaktadır. Pandemi döneminde müssterilerimiz işletmelerini kapattı, siparişlerini iptal ettiler veya ertelediler. Üretime 2 ay ara vermek zorunda kaldik, bu süreçte alacaklarımızı tahsil edemediğimiz için kısa vadeli borçlarımızı ödemekte zorlandık."

Ek olarak görüşmeci 8 şunları ilave etmiştir:

"Yurtiçi müşterilerimizden olan alacaklarımızın vadelerini 2-3 ay uzatmak zorunda kaldlk, siparişlerde bekletme ve iptaller oldu. Nisan ve Mayls aylarinda üretimimizi durdurduk. Bu süreçte sadece yurtdışı müssterilerimizden alacaklarımızı tahsil etmemiz likidite sorunumuzu çözmedi. Şirketimizin güçlü finansal yapısı olmasına ră̆men, pandemi ekonomik daralmaya neden oldu. Temmuz ayında bile yarı kapasiteyle çalışıoruz."

Görüşmeci 4, yukarıdaki görüşmecilerin aksine, pandemi döneminde eticaret yoluyla satış yaptığı için çalışma sermayesi bileşenlerinden kaynaklanan herhangi bir sorun yaşamadığını belirtmiştir. Şu yorumu yapmıştır:

"Pandemi döneminde e-ticaret kanalyyla satış yaptı̆ım için, alacakların tahsilatında, stokların devir hızında ve kısa vadeli borçlarımı ödemede sorun yaşamadim."

\section{İsletmenin Esas Faaliyet Gelirleri}

Görüşülen kişilerin çoğu Nisan ve Mayıs aylarında dünya ticaretinin durma noktasına gelmesi nedeniyle faaliyet gelirlerinin önemli ölçüde düştügünü belirtmiştir. Mart ayında yarı kapasitede çalıştıklarını, Nisan ayında üretimi durdurmak zorunda kaldıklarını belirtmişlerdir. Mayıs ayında üretime tekrar başladıklarını, ancak siparişlerin istenilen düzeyde olmadığını ifade etmişlerdir. Görüşmeci 1 ve Görüşmeci 5 şu yorumu yapmıştır:

"İ̧sletmemizin geliri pandemi nedeniyle önemli ölçüde düşü. Belirsizliğin devam etmesi nedeniyle bu yll geçen yllki seviyeye ulaşmamız mümkün değil."

"Siparişlerin teslimat sürelerinin uzamasl ve üretime ara vermek zorunda kalmamız, işletmemizin önemli ölçüde gelir kaybına neden oldu. Pandeminin 
Aralık 2021 Cilt 23 Sayı 2 (571-592)

yarattı̆̆ ekonomik belirsizlik tüm ülkeleri etkilediği için alternatif bir pazar bulamıyoruz."

Görüşmeci 2,3 ve 4, yukarıdaki görüşmecilerden farklı yorumlar yapmışlardır.

"Pazarda maske ve tıbbi tulum alanında ciddi bir rekabet olmasına răgmen, bu ürünlerin satışını yaparak gelir elde ettik ve işletmemizin sabit giderlerini karşılayabildik."

"Pandemi döneminde anti bakteriyel medikal tekstil ürünlerine yoğunlaştık, ancak bu ürünlerden istenilen düzeyde gelir elde etmemiz için pazarda bilinirliğe ihtiyacımız var."

"Pandemi döneminde ev tekstili grubunun toptan satışlarından gelir elde edemedik, ancak bu ürünleri e-ticaret kanalyyla satarak gelir elde ettik."

Işletmenin Giderleri ve Maliyetleri

İşletme yöneticileri tekstil üretim maliyetinde en önemli gider kalemlerinin enerji, hammadde ve işçilik olduğunu belirtti. Nisan ayında işletmelerin kapalı olmasına veya atıl kapasite ile çalışmasına rağmen, pandeminin getirdiği kısıtlamalar nedeniyle enerji sayaçlarının okunmadığını, ancak yine de yüksek bedellerle elektrik giderlerine katlanmak zorunda kaldıklarını ifade ettiler. $\mathrm{Bu}$ bilgilere, Görüşmeci 1, işletmenin kapalı olduğu dönemde kira giderlerine de katlanmak zorunda kaldıklarını eklemiştir.

Görüşmecilerin çoğu, pandemi döneminde normal kapasite ile çalışmadıkları için, kısa çalışma ödeneğinden yararlandıklarını ve işçilerin ücret \& sigorta giderlerinin devlet tarafından karşılandığını belirtmiştir. Görüşmeci 2 enerji ve elektrik giderleri hakkında şu yorumu yapmıștır:

"Üretimi durdurduğumuz dönemde bile enerji faturalarina yüksek bedel ödedik. İşçi ücretleri ve sigortaları için kısa çalışma ödeneğinden faydalandığımızdan bu giderler devlet tarafindan karşılandı."

Görüşmeci 4, pandemi döneminde e-ticaret kanalıyla satış yaptıklarından normal kapasite ile üretime devam ettiklerini ve bu nedenle kısa çalışma ödeneğinden yararlanmadıklarını belirtmiştir. Görüşmecilerden sadece 5, pandemi döneminde çalışanların motivasyonlarını artırmak amacıyla personeline nakdi destek verdiklerini ifade etmiştir.

Görüştüğümüz kişiler, Türkiye’de pandemi döneminde döviz kurlarındaki artışın hammadde maliyetlerini yükselttiğini belirtmişlerdir. Görüşmeci 7 şu yorumu yapti:

"Döviz kurunda artışa bağll olarak hammadde fiyatlarımız artıyor, bu durum maliyetlerin yükselmesine neden oluyor."

Görüştüğümüz kişiler, sipariş üzerine üretim yaptıkları için ağırlıklı olarak kişisel pazarlama tekniğini kullandıklarını ve bu nedenle pazarlama giderlerinin yüksek olduğunu belirtmişlerdir. Pandemi döneminde ise, bulaş riskine karşı önlem 
almak ve pazarlama giderlerini düşürmek için online toplantı ve görüşmelerin yapıldığını ifade etmiş̧lerdir.

Yukarıdaki bilgilere ek olarak Görüşmeci 4 ve Görüşmeci 3 şunları ilave etmiştir.

"Pandemi döneminde e-ticaret kanaliyla satıslarımızı arttırmak amactyla dijital görünürlüğ̈̈müzü arttırıcı yatırım giderlerine katlandık. Ayrıca, kendi markamızı oluşturmak amacıyla yatırım maliyetine katlandık."

Görüşmeci 3 bu durumu şöyle açıkladı: "Pandemi döneminde anti bakteriyel medikal tekstil ürünleri geliştirmek için ar-ge giderlerine katlandık."

Işsletme Bütçeleri

Görüşmecilerin çoğu, pandemi döneminde gelirlerindeki düşüşle başa çıkmak, maliyetlerini ve giderlerini düşürmek, nakit yaratmak için sıkı bütçe kontrolleri yaptıklarını belirtmiştir. Görüşmeci 8 , bu konuda şöyle yorum yaptı:

"2020 bütçe hedeflerine ulaşmamız mümkün değil. Pandemiden dolayı işletme operasyonlarında aksaklık finansal bütçemizi etkiledi. Bu süreçte alacaklarımıza odaklandık, yıllardır satış yaptığımız işletmelere kısa vadeli satı̧̧ yapıyoruz, yeni müşterilerimizle olabildiğince nakit çalışmaya çalışıoruz. Ayrıca bu süreçte giderlerimize odaklanarak, hangi kalemleri düşüreceğimizi araştırlyoruz."

Görüşmeci 5, pandemi döneminde işletme bütçesindeki sapmaları şöyle açıklamıştır:

"Pandemi döneminde katlandığımız maliyetlere Covid-19'un önlenmesi için kullandı̆̆ımız maske, koruyucu, dezenfektan gibi hijyen kalemleri eklendi. Ayrica, personelin yemeklerini tek kullanımlık kaplarda yemesini sağlamak amacıyla tek kullanımlık gıda kapları satın aldık. Üretim ve satışların istediğimiz düzeye gelmesi çok zor iken, gider ve maliyet kalemlerimiz artmaktadır. 2020 yılı için belirlediğimiz performans hedeflerine kaç yll sonra ulaşabiliriz bilmiyorum."

Görüșmeci 2 șu yorumu ekledi:

"Bu süreçte amacımız satış kaybımızın önüne geçmek, yani gelirlerimizin düşmesini önlemektir. Bunun için mevcut müşterilerimizin devamlıllğını sağlamak amacıyla fiyatlarımızı revize ederek, hizmet anlayışımızı yeniden belirledik. Öte yandan, işletme maliyetlerini azaltmanın yollarını ariyoruz."

Görüşmeci 4,yukarıdaki açıklamaların aksine, bu süreçte işletme bütçelerinin önemli ölçüde etkilenmediğini, ancak pandeminin yarattığı belirsizlikten kaçınmak için tasarruf tedbirleri aldıklarını belirtmiştir.

Işletmenin Sürdürülebilirliği

Görüşmecilerin çoğu, işletmelerinin sürdürülebilirliğini sağlamak amaciyla stok, alacak, borç ve maliyet yönetimi ilgili yeni kararlar aldıklarını ve bunları hayata geçirdiklerini ifade etmiştir. Görüşmeci 5, pandemi döneminde işletmenin sürdürülebilirliğinde maliyet kontrolünün rolünü vurgulamış ve alınan kararların bu dönemde yeniden gözden geçirilmesi gerektiğini belirtmiştir. Görüşmeci 6 , bu 
süreçte güçlü mali yapının önemini vurgulamıştır. Bu konudaki görüşünü şöyle ifade etmiştir:

"Pandemi bize her zaman zor zamanların gelebileceğini ve bunun için güçlü mali yapının olması gerektiğini akılda tutmamızı ögretti. Öncelikle alternatif pazarların önemini anladık. Alacakların kisa vadeli olmasl gerektiğini, borçlanmanın döviz bazlı değil TL bazlı olması gerektiğini gördük. Bu konuları dikkate alarak çalı̧̧malarımızı sürdüreceğiz."

Yukarıdaki görüşmecilerden farklı olarak, Görüşmeci 3, inovasyona dayalı yeni nesil tekstil ürünleri ile varlıklarını sürdüreceklerini belirtmiştir. Görüşmeci 4, ürünlerini e-ticaret kanalıyla satışlarını arttırmayı planladıklarını ve markanın yaratılması konusunda önemli adımlar attıklarını ifade etmiştir. Görüşmeci 2, pandemi döneminde zorunlu olarak ürün grubunu değiştirdiklerini, ancak bu durumun işletmeye pazarın ihtiyaçları doğrultusunda üretim yapma esnekliği sağladığını belirtmiştir.

\section{SONUÇ ve ÖNERILER}

$\mathrm{Bu}$ çalışmada, Covid-19 sürecinde KOBİ'lerin finansal görünümü araştırılmıştır. Çalışmanın ilk bölümünde elde edilen bulgular sonucunda; işletmelerin krizden etkilenme derecesi, sektördeki işletmelerin faaliyet konusuna göre değişmekle birlikte, pandeminin ilk etkisinin işletmelerin siparişleri üzerinde olduğu söylenebilir. Pandemi tekstil sektöründe yer alan teknik tekstil, ev tekstili ve örmeciler grubunu olumsuz etkilemezken, diş giyim kumaş üreticilerini olumsuz etkilemiştir. Dış giyim kumaş üreticilerine olan talebin durması hem eski hem yeni siparişlerin ertelenmesine ve iptaline neden olmuştur. Diğer taraftan, işletmenin faaliyetlerini iyileştirmek için kullandığı iş modeli krizin yönetilmesinde etkili olmuştur. Görüşmeci 4'ün işletmesi pandemi öncesi dijital yatırımlar yapması sonucunda e-ticaret kanalıyla satışlarına ve dolayısıyla üretime devam etmiştir. Aynı şekilde, Görüşmeci 3'ün işletmesi dış giyim ve ev tekstilinin yanı sıra anti bakteriyel medikal tekstil ürünü ürettiği için süreci firsata çevirmiştir. Görüşmeci 2, pandemide iş modelini değiştirmiştir. Pandemi öncesi yurtdışı pazara yönelik gömlek kumaşı üreten işletme, bu dönemde sabit giderlerini karşılayabilmek için, maske, tıbbi tulum üretmeye başlamıştır. Ayrıca, işletme yöneticileri pandeminin olumsuz etkilerini dile getirmiş olsalar da, çok az işletme bilimsel olarak SWOT analizi yapmıştır.

Çalışmanın ikinci bölümünde elde ettiğimiz bulgular şunlardır; görüşmecilerin çoğu, sipariş üzerine üretim yaptıkları için yüksek miktarda hammadde stoku bulundurmadıklarını, ancak pandemi döneminde siparişlerin iptali ve teslimat sürelerinin uzamasına bağlı olarak mamul stoklarını depoda bekletmek zorunda kaldıklarını belirtmiştir.

Görüşmecilerin çoğu, Türk Eximbank'ın alacak sigortası uygulamasını kullandıkları için yurtdışı alacaklarından doğan riskli alacaklarından tahsilat sorunu 
yaşamadıklarını, ancak yurtiçi müşterilerine tahsilat için ek süre vermek zorunda kaldıklarını belirtmiştir. Görüşmeciler, pandemi döneminde önce bankaya olan borçlarını ödediklerini, daha sonra ticari borçlarını yeniden yapılandırdıklarını belirtmişlerdir.

Görüşmecilerin çoğu, nakit dönüş süresinin uzaması nedeniyle finansman sorunları yaşadıklarını ifade etmiştir. Görüşmecilerden bir kısmı şirket ortaklarından borç alarak, portföyündeki çek ve senetleri iskonto ettirerek, bankadan kredi alarak finansman sorununu aşmaya çalıştıklarını belirtirken, diğer kısmı bu sorunu bankadan kredi alarak çözmeye çalıştıklarını belirtmiştir.

Çalışma sermayesi yönetiminde karşılaşılan sorularla ilgili olarak görüşmecilerin çoğu; alacakların tahsil süresinin uzadığını, siparişlerin ertelenmesi ve iptali nedeniyle üretimin durduğunu, teslimat sürelerinin uzadığını ve bu durumun kısa vadeli borçların ödenmesini zorlaştırdığını belirtmiştir.

Görüşmecilerin çoğu, Covid-19'un işletmelerinde ciddi gelir kayıplarına neden olduğunu belirtmiş, pandemi döneminde tüketmedikleri elektrik ödemeleri ve döviz kurundaki yükselişin bir sonucu olan hammadde giderlerindeki artıştan kaynaklanan sorunları vurgulamıştır.

Görüşmecilerin çoğu, pandemide işletme faaliyetlerinin aksadığını ve bunun işletme bütçesini olumsuz etkilediğini, giderleri düşürmek ve nakit yaratmak için alacaklarına odaklandıklarını ifade etmiştir. Görüşmecilerin çoğu, işletmelerinin sürdürülebilirliğini sağlamak için alacaklarının ve borçlarının vadelerini gözden geçirdiklerini ve sadece stratejik müşterilerine vadeli satış yapmayı planladıklarını belirtmiştir.

Sonuç olarak, Covid-19 salgın sürecinde işletmelerin finansal görünümü pandemiyi yönetebilme becerilerine göre değişiklik göstermektedir. Pandemi sürecinde e-ticaret kanalıyla satış yapan, anti bakteriyel medikal tekstil ürünleri üreten, maske, tıbbi tulum üretmeye başlayan işletmelerin finansal yapıları değişmemiştir. Diğer taraftan pandemiye bağlı küresel kilitlenme çoğu işletmeyi derinden etkilemiştir. Pandemi döneminde alacakların tahsilat süresinin uzaması, siparişlerin iptal edilmesi ve bunun sonucunda satış yapılamaması, müşterilerinin teslimatı ötelemesi çalışma sermayesi sorunu yaratmıştır. İşletmeler, bu sorunu ya kamu bankalarından aldıkları kredilerle ya da portföylerindeki çek ve senetleri vadesinden önce tahsil etmek amacıyla bankaya iskonto işlemi yaptırarak çözmeye çalışmışlardır. Çalışma sermayesi döngüsünün bozulması sonucunda işletmelerin borç yükü arttığı için, borç/özkaynak oranını artmış ve bu da finansman giderlerini arttırmıştır. Diğer taraftan, bu süreçte gelirlerdeki düşüş hammadde giderleri ile enerji giderlerinden kaynaklanan üretim maliyetlerindeki artış, faaliyet kârının erimesine neden olmuştur. $\mathrm{Bu}$ ise, işletmenin esas faaliyetlerinden nakit yaratma kabiliyetini olumsuz etkileyecek ve çalışma sermayesi sorununun kısır döngüye girmesine neden olacaktır. Bu süreçte KOBI'ler sürdürülebilirliklerini sağlamak 
Aralık 2021 Cilt 23 Sayı 2 (571-592)

için, gider ve maliyet kalemlerine odaklanarak sıkı bütçe kontrolleri yapmakta, ticari alacaklarının yönetimini gözden geçirmektedir. Birkaç işletme dışında, pandeminin iş modellerinde değişikliğe neden olmadığı belirlenmiştir. Bu süreçte en yaygin eylem pazarlama faaliyetlerinin dijital ortamda devam ettirilmesidir. Ayrıca, pandemi deneyiminin işletmelerin inovasyona ve dijitale yatırım yapmasına, tedarik zincirlerini tekrar gözden geçirmesine neden olmadığ 1 belirlenmiştir. Çalışmanın sonuçları, bu konuda yapılan çalışmaların sonuçlarını doğrulamaktadır (Lu vd., 2020 ; Cowling ve Brown., 2020; Shafi, Liu ve Ren 2020; Qamruzzaman; 2020; Thorgren ve Williams, 2020; Omar vd., 2020).

Covid-19'un pandemisinin boyutları değiştikçe işletmelere etkileri de farklı olacaktır. Bu nedenle, KOBİ'lerin küresel krizi yönetebilmeleri, sürece entegre olabilmeleri için rehberliğe ihtiyaçları vardır. Bu noktada, Ticaret ve Sanayi Odaları bünyesinde yer alan sektör kurullarının küresel salgının işletme faaliyetlerine yönelik etkilerinin azaltılması ve finansal yönetimde karşılaşılan sorunların çözülmesi için sektör ile çalışmalar yapması önem arz etmektedir.

Araştırmanın sağladığı katkıların yanı sıra bazı kısıtları bulunmaktadır. Araştırmanın Denizli İl'inde tekstil sektöründe faaliyet gösteren dokuz KOBİ yöneticisi ile yapılan görüşme yönteminde elde edilen verilere dayandırılması önemli bir kısıt olarak değerlendirilmelidir. Gelecek araştırmalarda, Covid-19'un farklı sektörlerde yer alan KOBİ'lerin finansal yapısını nasıl etkilediği, nitel ve nicel araştırma teknikleri birleştirilerek incelenebilir.

\section{KAYNAKCA}

Apak, S., Erol, M., ve Atmaca, M. (2012). Accounting Measures to be taken for The Enterprises in Difficulty during Times of Economic Crisis: A Study on Small and Medium- Sized Enterprises, African Journal of Business Management, 6 (23): 6832-6844.

Atmaca, M. (2016). Finansal Oranlar Aracılığıyla Çalışma Sermayesi Bileşenlerinin Kârlılığa Etkisi: Borsa İstanbul'da İşlem Gören Kimya, Plastik ve Kauçuk Şirketlerinde Bir Araştırma, Yönetim Bilimleri Dergisi, 14 (28):636.

Cowling, M., ve Brown, R. (2020). Did You Save Some Cash for a Rainy Covid-19 day? The Crisis and SMEs, International Small Business Journal Researching Entrepreneurship, 1-12.

Demir, Ö., Aydın, D., ve Sezgin, E. (2019). KOBI'lerin Finansal Sorunlarının İncelenmesinde Dış Kaynağın Rolü: Diyarbakır İli Örneği, Muş Alparslan Üniversitesi Sosyal Bilimler Dergisi, 7 (2),227.

Eggers, F. (2020). Masters of Disasters? Challenges and Opportunities for SME's in Times of Crisis, Journal of Business Research, 116,199-208.

Eğri, T., ve Doğaner, A. (2020). COVID-19 ve Ekonomik Kriz: Kobiler Özelinde Bir Değerlendirme ve Politika Önerileri. İstanbul Ticaret Üniversitesi Sosyal Bilimler Dergisi, 19 (37), 129-133. 
He, S., ve Ausloss, M. (2017). The Impact of the Global Crisis on SME Internal vs. External Financing in China, Banking and Finance Review, 9 (1), 117.

Juergensen, J, Guimon, J. ve Narula, R. (2020).European SMEs Amidst the COVID-19 Crisis: Assessing Impact and Policy Responses, Journal of Industrial and Business Economics, 47, 499-510.

Kraus, S., Clauss, M., Gast, J., Zardini, A. ve Tiberius, V. (2020). The Economics of COVID- 19:Initial Empirical Evidence on How Family Firms in five European Countries Cope with the Corona Crisis, International Journal of Entrepreneurial Behavior \&Research, 26 (5),1067-1092.

Kottika, E., Özsomer, A., Ryden, P. ve Theodorakis, I. (2020). We Survived this! What Managers Could Learn from SMEs who Successfully Navigated the Greek Economic Crisis, Industrial Marketing Management, 88, 352-365.

Lu, Y, Wu, J, Peng J., ve Lu, L. (2020). The Perceived Impact of the Covid19 Epidemic: Evidence from a Sample of 4807 SMEs in Sichuan Province, China, Environmental Hazards, 19(4), 323-340.

McKinsey Global Institute, Global freight flows after COVID-19: What's next?, July 2020

https://www.mckinsey.com/ /media/McKinsey/Industries (10.08.2020)

OECD a (2020), https://www.oecd.org/economic-outlook/june-2020/

OECD b (2020),

http://www.oecd.org/coronavirus/policyresponses/coronavirus-covid-19-SMEspolicy-responses, (17.09.2020)

Omar, A., Ishak, S. ve Jusoh, A. (2020). The Impact of Covid-19 Movement Control Order SMEs' Business and Survival Strategies, Malaysian Journal of Society and Space, 16 (2), 139-150.

Proença, P., Laureano, R., ve Laureano, L. (2014). Determinants of Capital Structure and 2008 Financial Crisis: Evidence from Portuguese SMEs, ProcediaSocial and Behavioral Sciences, 150, 182-191.

Shafi, M., Liu, J., ve Ren, W. (2020). Impact of Covid-19 Pandemic on Micro, Small and Medium- Sized Enterprises Operating in Pakistan, Research Globalization,2,1-4.

Thorgren, S. and Williams, T. (2020). Staying Alive During an Unfolding Crisis: How SMEs Ward off Impending Disaster, Journal of Business Venturing Insights, 14, 1-11.

Tuğay, O., Dalğar, H., ve Tekşen, Ö. (2014). Ekonomik Kriz Dönemlerinde İşletmelerin Muhasebeye Karşı Tutumlarındaki Değişiklerin Belirlenmesine Yönelik Bir Araştırma, Muhasebe ve Finansman Dergisi, Ocak, 3. 
Turner, D. W. (2010). Qualitative Interview Design: A Practical Guide for Novice Investigators. The Qualitative Report, 15(3), 757-759.

TÜiK (2015) Küçük ve Orta Büyüklükteki Girişim İstatistikleri, TÜiK Haber Bülteni, Say1: 21864.

TÜiK (2020). Dış Ticaret İstatistikleri Haziran, TÜiK Haber Bülteni, Sayı: 33854

TÜRKONFED (2020),

https://www.business4goals.org/wp-content/uploads/2020/04/COVID-19-

Isletme Etki ve İhtiyaç-Anketi.pdf,(25.08.2020)

TÜRMOB - Türkiye Serbest Muhasebeci Mali Müşavirler ve Yeminli Mali Müşavirler Odaları Birliği (2020), "Korona Salgınının Türkiye Ekonomisine Etkisi Değerlendirmeler Raporu", https://www.turmob.org.tr/haberler/f599274fc33d- 48ff-bfb8-koronasalgininin-turkiye-ekonomisine-etkisi--değerlendirmelerve öneri-raporu (25.09.2020)

Uyanık, S., ve Çeliker, D. (2019). Türk Tekstil Endüstrisi Genel Durumu, Teknik Bilimleri Dergisi, 9(1), 33-35.

WTO (2020), https://www.wto.org/english/news_e/pres20_e/pr855_e.htm (29.08.2020).

Yazdanfar, D. ve Öhman, P. (2017). Financial Distress Determinants among SMEs: Empirical Evidence from Sweden, Journal of Economic Studies, 47(3), 547- 559.

Yıldırım, A., ve Şimşek, H. (2016). Sosyal Bilimlerde Nitel Araştırma Yöntemleri, Ankara: Seçkin Yayınevi.

Zubair, S, Kabir, R. ve Huang, X. (2020). Does the Financial Crisis Change the Effect of Financing on Investment? Evidence from Private SMEs, Journal of Business Research, 110,456-463.

Zimon, G., ve Dankiewicz, R. (2020). Trade Credit Management Strategies in SMES and the Covid-19 Pandemic-A Case of Poland, Sustainability, 12 (5),116.

Qamruzzaman, M.,( 2020). COVID-19 Impact on SMEs in Bangladesh: An Investigation of What They Are Experiencing and How They Are Managing?

http:// ssrn.com/a654126 (07.08.2020) 
EK 1: Görüşme Soruları

\section{EKLER}

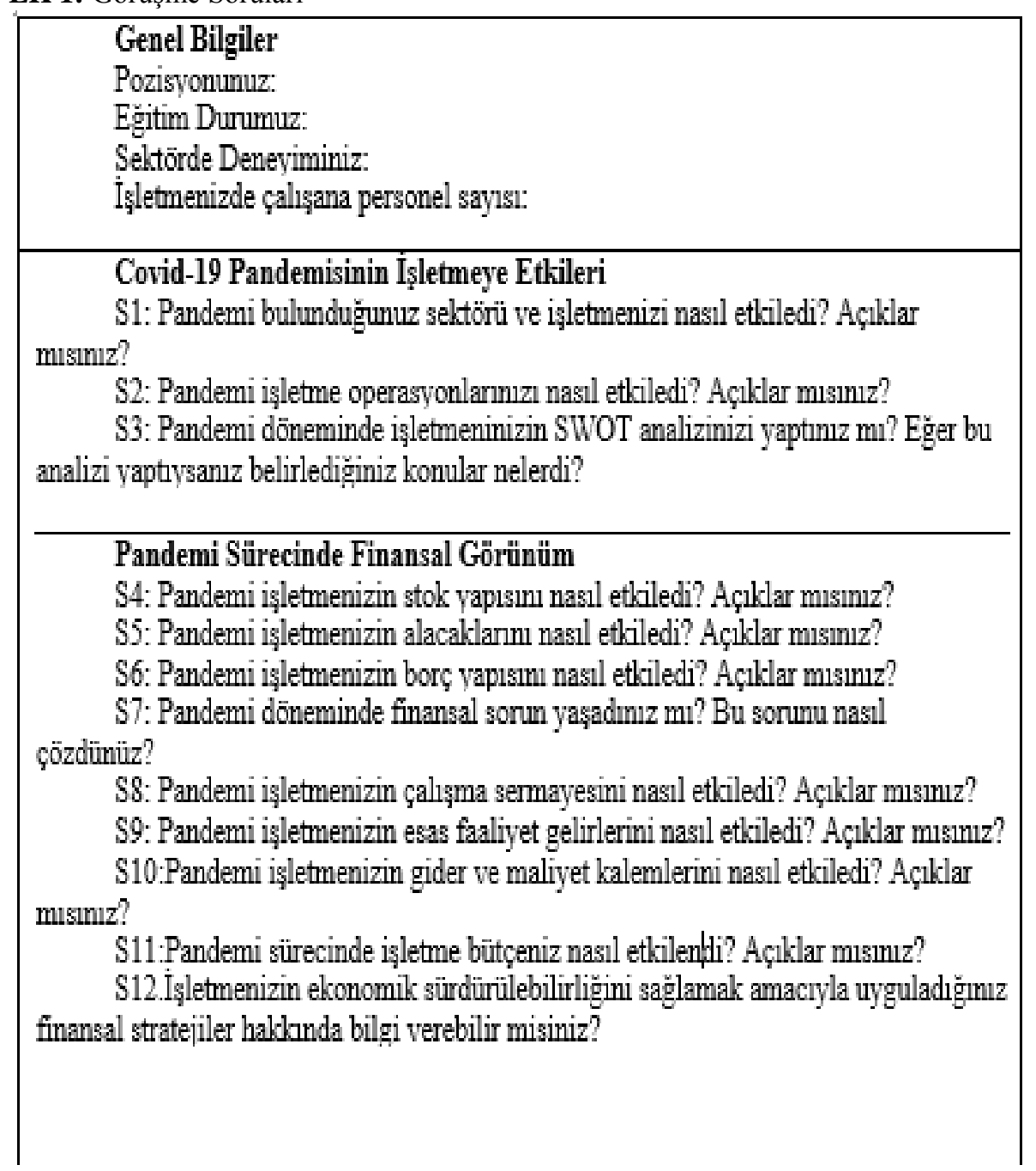

